\title{
Framing policy problems and solutions in education policymaking: Pre-vocational education in Norwegian lower secondary school
}

European Educational Research Journal

(C) The Author(s) 2021

Article reuse guidelines: sagepub.com/journals-permissions DOI: 10.1 I $77 / 147490412$ II 044602 journals.sagepub.com/home/eer

@SAGE

\author{
Maike Luimes \\ Faculty of Educational Sciences, University of Oslo, Oslo, Norway
}

\begin{abstract}
This article investigates policymaking for Norwegian lower secondary education, with a focus on policy problems and solutions emphasising pre-vocational education. The data consist of official policy documents such as Green and White Papers, hearings, propositions to the parliament, protocols of parliamentary debates and votes in the parliament. The conceptual framework focuses on framing in policymaking and policy problems and solutions. Results reveal that dropout, difficulties in adapting education to the pupils and a gap between the content of schooling and the demands of the world of work are framed as the main policy problems. Different policy solutions emphasising pre-vocational education are presented as legitimised responses to these problems. The three policy problems can be defined as complex issues. Despite the proposed policy solutions, these are not enacted in the curriculum in line with the discussions and votes in parliament. This could be attributed to conflicting values and purposes of Norwegian education. These differences raise the question of whether the problems faced by Norwegian comprehensive schooling are taken for granted, as the proposed solutions appear to be insufficient in dealing with the defined problems.
\end{abstract}

\section{Keywords}

Education policy, pre-vocational education, framing, policy problems, policy solutions, policymaking, curriculum reform, Norway

\section{Introduction}

Policymaking and the reasons to initiate reforms can be traced back to different causes, such as changes in society, specific policy problems (Kingdon, 1995) or international and transnational policy influences (Karseth and Engelsen, 2013; Scholl, 2012; Sivesind et al., 2012; Sundberg and Wahlström, 2012). Despite a high degree of stability in education policy, such as in the 
composition of the curriculum and schools themselves (Cuban, 1990; Goodson, 1995, 2001, 2014; Hopmann, 1999), education policy is subject to frequent reforms. Such stability can be attributed to the values and purposes of education to be supported in the policymaking process, with which the objectives of a reform have to be aligned (Labaree, 1997). Nevertheless, education can have competing values and purposes, resulting in contradictory policy means and further extenuated effectiveness.

For more than a decade, one specific cause of education policy reforms has been a focus on the link between education and the world of work for the benefits of both individuals and the global knowledge economy (Sundberg and Wahlström, 2012; Young, 2008). In this context, the Organisation for Economic Co-operation and Development (OECD, 2011) highlights pre-vocational education as a policy mean for solving key problems in lower secondary schools in general and as a suitable approach in the Norwegian context in particular. One key problem pre-vocational education shall solve, according to the OECD, is the dropout rate from upper secondary education. The secondary graduation rate in Norway is only slightly above the OECD average (OECD, 2020) and in the midfield of the countries included in the overview.

During the last decade, education policy reforms have led to curriculum revisions that resulted in more pre-vocational education in Norwegian lower secondary education. For instance, new school subjects, such as the world of work-subject (arbeidslivsfaget), have been introduced to the curriculum (Kunnskapsdepartementet, 2012). This leads to the question of whether changes in society, policy problems and/or international and transnational policy influences cause policy reforms emphasising pre-vocational education in the curriculum.

This article focuses on policymaking and education reforms in the Norwegian lower secondary school curriculum. More precisely, it analyses curriculum reform with a focus on pre-vocational education in lower secondary education from 2003 to 2013. In doing so, this work addresses the following research question: how are the policy problems and solutions with regard to pre-vocational education framed in the policymaking process? Hence, through an analysis of official policy documents, this article identifies the frames used to describe and make sense of policymaking that leads to more pre-vocational education in Norwegian lower secondary school. Pre-vocational education comprises school subjects and topics focusing on the world of work and the transition to vocational education and training (VET) as well as work that are part of ordinary lower secondary education (Berger et al., 2012; Luimes and Karseth, 2019). In Norway, the elective world of worksubject, which introduces tasks from VET adjusted to lower secondary education to the pupils (Utdanningsdirektoratet, 2015), is an example of pre-vocational education. The policy documents analysed in this study include Green and White Papers, propositions from parliamentary committees, official hearings and protocols of debates as well as votes in Stortinget (the Norwegian parliament).

Norway represents an interesting case, because a focus on pre-vocational education has led to several curriculum revisions in the country during the last decade (Luimes and Karseth, 2019). By investigating the political process that initiates policy reforms of school curricula, this study focuses on the process leading up to actual curriculum reform. Previous studies on curriculum reform have focused on how heads of school and teachers - as agents of change - respond to new policies in schools (Mølstad et al., 2020; Prøitz et al., 2019). However, a focus on the framing of arguments for pre-vocational education in relation to curriculum reform is largely missing in the literature. Therefore, this study is a necessary addition to the literature, as it describes the input into the curriculum resulting in enactment of reforms in schools. Further, this article focuses on the integration of education and the world of work in Norwegian lower secondary education. Most studies on this area have focused on VET (Alexiadou et al., 2019). For instance, a special issue of the European Educational Research Journal (18(3)) on VET in the Nordic countries did not 
consider pre-vocational education (Nylund and Rosvall, 2019). Thus, in this regard, this study also presents a relevant addition to the literature.

The article is organised as follows. First, I start with a description of the Norwegian context, with emphasis on the Norwegian lower secondary school curriculum and policymaking. Then, I position the article in relation to approaches to policymaking, with emphasis on the concept of framing and policy problems and solutions. The analytical framework is based on these perspectives. Afterwards, I present the research approach and analysis of the official documents. Finally, the discussion focuses on policy problems and solutions, framing, conflicting values and purposes in education as well as the degree to which it is pretended that these problems are solved or accepted despite the curriculum reform.

\section{The Norwegian context}

\section{Norwegian lower secondary school curriculum}

The Norwegian education system is a comprehensive school system characterised by an inclusive approach without organisational differentiation (Imsen and Volckmar, 2014). Thus, all pupils of a cohort attend the same school system, independent of their abilities and possible special needs. Most pupils attend the public education system, with only $4.2 \%$ of all pupils in primary and lower secondary education enrolled in private schools in 2019 (NTB (Norwegian Telegram Office), 2020). The principle of adapted education (tilpasset opplcering), which is part of the Education Act, is applied to meet the needs of all pupils in the comprehensive school system. Adapted education emphasises equal education for all pupils in accordance with their respective abilities. This principle aims to offer equal access to education and equal opportunities for all children (Karseth and Møller, 2020). The establishment of a comprehensive school system in Norway is closely related to the social democratic ideology that has been dominant since the 1930s and places great emphasis on equality (Telhaug et al., 2004, 2006). Such an inclusive approach to schooling aims to contribute to social integration and provision of equal opportunities.

Teaching in Norwegian comprehensive schools is based on a national curriculum and the curriculum in focus in this study is the curriculum LK06. ${ }^{1}$ Research shows that the composition of the curriculum is characterised by stability and a consolidated position of academic subjects, both in Norway and elsewhere (Goodson, 1995, 2001, 2014; Luimes and Karseth, 2019). Although prevocational education has gained more space in LK06 than in the previous curricula, its role seems less important than policy texts such as White Papers indicate. This raises important questions regarding which problems pre-vocational education was intended to solve and whether it plays a less important role in the curriculum than indicated in policy documents.

\section{Policymaking}

Policymaking in Norway often starts with the government giving a mandate to an ad hoc advisory commission concerning an investigation of a policy problem, including the examination and proposal of potential solutions (Stortinget, 2017). Advisory commissions include representatives from academia, the civil service, interest groups and the private sector. The work of such an ad hoc advisory commission results in a Green Paper (Norges offentlige utredninger (NOU)) which is sent out as an official hearing in case the government decides to follow up on the investigated policy problem. During the hearing process, public institutions, organisations and associations connected to the topic of the Green Paper are invited to respond to the issue at hand and the proposed recommendations. Some hearings are also open to public response. 
In the following policy process, the ministry responsible for the policy area in question examines the issue and prepares a White Paper (Melding til Stortinget (St.meld./Meld.St.)), which presents the policy issue and includes proposals and recommendations for policy reform (Stortinget, 2018). The White Paper is sent to the government, which discusses the issue in a cabinet meeting and proposes it to the parliament, Stortinget. Further, Stortinget forwards the White Paper to a committee that writes a proposition before presenting it to Stortinget again. Then, the members of the parliament discuss and debate the issue and the policy proposals before voting on the proposal. These debates and votes are documented through a written protocol.

The results of policymaking on the political level constitute the framework for the curriculum, which is then developed and formulated on the programmatic level (Hopmann, 1999), in Norway by the Norwegian Directorate for Education and Training. These levels are independent and interdependent; however, they are generally autonomous, as there is no linear connection between them. The public discourse on the political level is the standard of public education, which has to be aligned with 'the school practical common sense' (Hopmann, 1999: 96) in schools through the curriculum work on the programmatic level. Both the expectations of politicians and pedagogical professionals working in the education system have to be met by the work conducted on the programmatic level.

\section{Policymaking: framing policy problems and solutions}

Policymaking is the result of political processes wherein the issues at stake are presented and discussed, resulting in the passage of policy means. However, political issues at stake exist not as facts nor are they predefined; instead, they are constructed by politicians and policymakers. Indeed, any 'issue can be viewed from a variety of perspectives and be construed as having implications for multiple values or considerations' (Chong and Druckman, 2007: 104). The way an issue is considered and presented is called 'framing'. The concept of framing originated in Bateson's (1972) studies on animal behaviour. Since then, it has been introduced to public policy studies by Rein and Schön (1977) and to social movement studies by Goffman (1974). Daviter (2007: 654) defines framing as 'the process of selecting, emphasizing and organizing aspects of complex issues according to an overriding evaluative or analytical criterion'. In other words, framing results in sensemaking of reality, and the actors who frame the issue simultaneously give sense to it (Gioia and Chittipeddi, 1991). Given that certain aspects of an issue are selected and emphasised in the framing process, other aspects are automatically de-emphasised or left out. Framing is a dynamic and collaborative process amongst different actors (Benford and Snow, 2000), resulting in the construction of stable frames (MacLachlan and Reid, 1994; van Hulst and Yanow, 2016).

Further, framing has been used in other disciplines and fields such as artificial intelligence and psychology, linguistics, communication studies, dispute resolution, music, anthropology, ethnography and sociology (van Hulst and Yanow, 2016). The concept of framing has also been applied in educational research. For instance, Coburn has applied Goffman and conducted several studies of policymaking and implementation processes (see e.g. Coburn, 2006; Coburn et al., 2009), while Verger (2012) has studied framing and the promotion of public-private partnerships in education in low-income contexts. Therefore, the concept of framing is also a relevant approach for education policy analysis.

In policy studies, research on policy framing focuses on 'the role of political issue definitions in the policymaking process' (Daviter, 2007: 654). According to Rein and Schön (1977), framing in policymaking usually results in converting a situation into a problem. Thereby, both knowledge and values are organised into a frame, and certain actions are legitimised as responses. At the same time, the constructed frame excludes other policy means and solutions to the respective problems. According to Béland and Howlett (2016), ideas such as worldviews, ideologies, cognitive filters 
and causal beliefs are also important in framing and in constructing policy problems and solutions. Especially in policymaking regarding education policy, the purpose of schooling and its associated values are considered important aspects (Labaree, 1997). Labaree (1997) further argues that the purposes and objectives of schooling can be competing and incommensurate, resulting in conflicts and inefficient structures and policy means. Specifically, these differences can result in policy means that either reinforce or undermine each other. Thus, following Labaree, a consequence of this is that different policy means can push schools in opposite directions at the same time. In addition to this incommensurability, certain objectives and purposes can dominate others, thereby exacerbating the imbalance and struggles created by existing differences. This aspect is important in policymaking, because the purposes and values that are the foundation for policy means decide whether these are supported (Labaree, 1997).

Given that the framing of a policy issue also entails defining the policy problem that is supposed to be solved, there is a need to characterise current policy problems. Policy problems are often represented in the literature as either 'wicked' or 'complex'. The concept of wicked problems originated from Rittel and Webber (1973), who stated five decades ago that future policy problems would be more complex, non-linear and demanding compared to problems policymakers had previously addressed. This leads to difficulties related to the design and implementation of policies. Wicked problems are characterised by being difficult to define, being connected to other problems and lacking a clear (set of) solutions(s). Peters (2017: 386) is critical of the characterisation of policy problems as wicked problems, describing such characterisation as 'a fad in the academic literature', despite acknowledging that policy problems nowadays are both difficult and complex, even to a greater extent than those described by Rittel and Webber in the 1970s.

Instead, Peters (2017) argues that relatively few problems actually meet all the characteristics of wicked problems, as defined by Rittel and Webber (1973). Independently of whether problems are wicked, Peters emphasises that governments may have to accept that many of these problems actually cannot be solved in a definitive way. This applies to most problems faced by governments nowadays. Therefore, Peters argues for focusing on the complexity of policy problems instead. Complexity emphasises the absence of a linear relationship amongst variables; instead, 'small shifts (especially in the initial condition) may produce large differences in the outcome of the systemic dynamics' (Peters, 2017: 386).

Based on the presented concepts, I will focus on the frames that are used to describe and make sense of policymaking, resulting in curriculum reforms that emphasise pre-vocational education in Norway. Inspired by the concept of framing, this study will focus on the frames presented in the documents describing policy problems and solutions emphasising pre-vocational education; that is, which problems are selected and which solutions are proposed to deal with these problems. The various documents comprising the empirical data of this study add different kinds of information with which to answer the research questions. The Green and White Papers present the frames describing policy problems and solutions and the purpose of education as it is defined in the Norwegian education system. However, these documents have different statuses, as Green Papers are the result of the work of an ad hoc advisory commission describing and proposing policy problems and solutions, whilst White Papers describe policy problems and solutions that potentially result in policy reform, as proposed to the Stortinget. The descriptions of policy problems and solutions in Green and White Papers do not have to be congruent, as the latter can either be based on the former or focus on different policy problems and solutions. In this article, most policy problems and solutions have been addressed in both Green and White Papers, despite the fact that some policy solutions have been adjusted in the policymaking process. Propositions from parliamentary committees and protocols of debates and votes in the Stortinget can give more insights into the descriptions of the frames, as the problems and solutions can be elaborated, amongst others, from the different perspectives the political parties have on the issues. 
Official hearing documents offer different frames concerning the same issues, as they usually criticise Green Papers and describe different policy solutions to those presented. On the basis of the results of the analysis, which summarise the frames of policy problems and solutions emphasising pre-vocational education and those describing the responses of different organisations in the hearing process, I discuss whether these policy problems are described as complex. Further, I focus on policymaking, with an emphasis on pre-vocational education related to the values and purposes of Norwegian education. Based on Labaree (1997), I reflect on how some policy solutions are scaled down in the policymaking process and whether this can be related to conflicting values and purposes of education. Finally, I discuss the degree to which the described policy problems are actually accepted, even though solutions that should solve them are enacted.

\section{Methods}

In accordance with the theoretical perspectives presented above, which focus on the framing of policy problems and solutions in policymaking processes, this qualitative study examines the frames used to make sense of the curriculum reform proposed in the selected policy documents. Specifically, I investigate the framed policy problems and solutions leading to curriculum reform, with an emphasis on pre-vocational education.

The official policy documents comprising the empirical data for this study were published between 2003 and 2013. These were selected because they represent all documents addressing the issue of pre-vocational education leading to reforms of LK06 for Norwegian lower secondary education. The selected documents include Green and White Papers, official hearing documents related to the Green Paper, propositions of political committees and protocols of discussions and votes in the Stortinget. This selection consists of documents that initiated the reform process and resulted in the curriculum itself, as well as documents that led to revisions in LK06 after its enactment. The period from 2003 to 2013 is relevant for this study, because policy problems and solutions with emphasis on pre-vocational education have been discussed during this timeframe. Quotes from the documents are my own translations.

In the following section, I provide a more detailed explanation of which approach I chose for the selection of the documents and the time period. I started by conducting an overview of all Green and White Papers related to the curriculum LK06 reform. This reform process began in 2002 with the appointment of an ad hoc commission to investigate the content, quality and organisation of primary and lower secondary education. The appointed commission published two Green Papers, which were sent out in an official hearing process. Further, the Ministry of Education prepared a White Paper that the government sent to the Education and Science Committee, which, in turn, prepared a proposition for debate and vote by the Stortinget. This policy process resulted in the LK06 curriculum, which has been subject to major changes since its enactment. For instance, new school subjects were added to the curriculum after it was introduced. The policy reforms after 2006 were the result of similar policymaking processes, although the government ordered no further Green Papers on the issue at hand.

After making an overview of all documents related to LK06, I read the introductions of the documents and their tables of contents to gain an understanding of their contents as well as the topics they address. Based on this insight, I decided which Green and White Papers were relevant for the scope of this study (i.e. those discussing pre-vocational education). In total, this included one Green Paper and five White Papers published between 2003 and 2013. In the next step, I collected relevant documents related to the chosen Green and White Papers. These include the hearing documents connected to the Green Paper and the propositions of political committees, protocols of discussions and votes in the Stortinget related to each of the White Papers, resulting in 20 different types of sources (see Appendix 1 for an overview of all documents). 
The analytical approach is inspired by a hermeneutic approach (Ricoeur, 1981). I read all the documents thoroughly and summarised the contents of all the different chapters, going back and forth between the whole texts and their chapters. In my reading, I focused on frames emphasising policy problems and solutions, with a focus on pre-vocational education and the role of the world of work. On the basis of these summaries, I decided which chapters were relevant for this specific analysis and briefly summarised the findings from these relevant chapters. Concerning the replies of the hearing of the Green Paper, I made an overview of all 156 replies to the Ministry of Education Then, using this list, I selected the 33 replies, which I rated as possibly concerned with pre-vocational education and the role of the world of work in education. Therefore, the replies I analysed are mostly from organisations representing different vocational fields, worker's unions, research institutes conducting research with a focus on the world of work, and several Norwegian ministries. Concerning the debates in the Stortinget, I read all the statements made by the politicians and summarised those debating contents deemed relevant for this analysis. Altogether, this resulted in a 44-page summary of the analysed documents.

Further, I used NVivo in analysing the documents and coded the parts of the documents that I identified as relevant for the scope of this study. The coding process dealt with the frames of policy problems and solutions emphasising pre-vocational education and the purpose of education. These frames describe and make sense of the curriculum reforms leading to pre-vocational education in Norwegian lower secondary education.

Based on the coded text parts, I went back and forth between the documents and their parts again to structure the findings. In the following section, I present the findings, starting with the frames of both policy problems and solutions, with an emphasis on pre-vocational education, followed by a presentation of the frame of purpose of education.

\section{Policy frames emphasising pre-vocational education in Norwegian lower secondary education}

In this section, I present the results of the document analysis. The first part outlines the framed policy problems and solutions highlighted in the documents, with an emphasis on pre-vocational education in Norwegian lower secondary education. The second part presents the frames of the purpose of education and the role of the world of work in education, which represent the values and purposes of education in Norwegian lower secondary education.

\section{Frames of policy problems and solutions}

The contents of the analysed White Papers are presented in a certain structure that leads to frames describing policy problems and policy solutions. The different White Papers describe certain issues, focusing on different aspects of the education system as a policy problem. At the end of each described policy problem, policy means are described as solutions to the defined problems. Policy reform resulting in pre-vocational education is framed as a solution to three different policy problems: school dropout, challenges in offering adapted education, and a gap between education and the content of schooling. In the following sections, these problems and their solutions are presented.

\section{School dropout}

One policy problem emphasised in several of the analysed documents is the school dropout rate in upper secondary education (see e.g. Ministry of Education, 2008, 2009, 2011). Based on data from Statistics Norway published in 2008, White Paper no. 31 (Ministry of Education, 2008) highlighted 
that the total dropout rate was approximately 30\%. The highest dropout rate was in VET, which was evidenced by the fact that although ' $84 \%$ in academically oriented upper secondary education obtain the final degree within five years, the corresponding percentage for pupils and apprentices in VET was 54\%' (Ministry of Education, 2008: 19). Several solutions have been proposed and adopted to reduce the number of dropouts from upper secondary education. For instance, the Church, Education and Science Committee (2008: 9) suggested 'a particular focus on quality and content in lower secondary school' including 'improved learning outcomes and more motivating education that can contribute to the reduction of school dropout in upper secondary education'. Some members of the committee, namely those representing the political parties Fremskrittspartiet $(\mathrm{FrP})$, Kristelig Folkeparti $(\mathrm{KrF})$ and Venstre $(\mathrm{V}),{ }^{2}$ proposed that pupils who struggle with theoretical subjects 'should be offered a more practical everyday school experience' (Church, Education and Science Committee, 2008: 10). This emphasis on motivation and a more practical approach to schooling has resulted in two policy solutions promoting career guidance and more practical experiences in school.

Career guidance was strengthened through a new elective school subject called elective programme subject (programfag til valg), which was proposed in the preparation of the reform that resulted in the curriculum LK06 (Ministry of Education, 2004; NOU, 2003). This subject was offered for two school years, starting when LK06 was first enacted in autumn 2006 and ending in spring 2008. The policy documents revealed that the purpose of the elective programme subject was to prepare pupils for their choice of upper secondary education by offering them a sample of the different tracks and programmes in both academically-oriented upper secondary education and VET, adjusted to lower secondary education (Church, Education and Science Committee, 2004; Ministry of Education, 2004). From autumn 2008 onwards, the elective programme subject was replaced by the mandatory subject choice of education (utdanningsvalg).

For more practical experiences in school, an elective entitled world of work-subject (arbeidslivsfaget) was proposed after LK06 was introduced (Ministry of Education, 2009). This subject is a clear pre-vocational mean in which pupils engage in tasks with products and services related to VET. The subject is offered as an alternative to a foreign language or supplementary studies in Norwegian/Sami, English and mathematics. The elective was piloted in the school year 2009-2010 and was subsequently extended to more schools in the following school year (Bakken et al., 2013). Further, the pilot was proposed to be extended to all municipalities interested in offering the subject to their pupils (Ministry of Education, 2011). This proposal was enacted in the 2012-2013 school year. Then, a policy proposal suggested that the world of work-subject should become mandatory if the final evaluations of the pilot were positive (Ministry of Education, 2013). Despite this proposal and the results of the evaluations, it was decided that all schools could offer the world of work-subject as an alternative to foreign language or supplementary studies in Norwegian/Sami, English and mathematics, instead of making it a mandatory part of the composition of subjects in the curriculum (Kunnskapsdepartementet, 2014). This compromise highlights how the emphasis on pre-vocational education in lower secondary education that accompanied the introduction of the world of work-subject was weakened.

During the preparation of LK06, a new school subject called technology and design with the purpose of combining theory and practice was proposed (NOU, 2003). However, this solution was scaled down in the policy process. Instead, it was suggested that technology and design could be incorporated in the curricula of relevant subjects (e.g. science and art and crafts) by including competency goals that address technology and design (Ministry of Education, 2004). Hence, the proposed solution in the policy process changed from a proposal requesting teaching hours for a 
new subject to a solution without this demand. Furthermore, it is difficult to distinguish whether competency goals addressing technology and design were included in the curriculum or not, as themes related to technology and design might have been included in the respective subject curricula independently of this proposal.

\section{Challenges in offering adapted education}

In the Norwegian comprehensive school system, the principle of adapted education is part of the Education Act and is also mentioned in the policy documents. For instance, NOU (2003: 83) states that 'the starting point for nowadays primary and lower secondary education is that education shall be adapted to the pupils. Thereby, education shall be adapted to include all.' However, the analysed policy documents problematise that the needs of the different pupils are not met adequately, in line with the principle of adapted education. This is due to the small variety in teaching and the content of schooling that favours academic knowledge. For instance, the Education and Science Committee reacted to the policy proposals by arguing:

To meet different needs and the breadth in the group of pupils, it is necessary that school is given the opportunity to offer greater variety in teaching. The Committee supports the goal in the White Paper [Meld.St.22 2010-2011] concerning more practical approaches throughout all teaching and in schools' organisations. (Church, Education and Science Committee, 2011: 3)

Furthermore, the document states that 'the Committee wants to underline the necessity of placing practical skills and knowledge on equal terms with academic knowledge in education' (Church, Education and Science Committee, 2011: 3). This statement proves that another policy problem addressed in the documents is related to comprehensive schooling and the difficulty of adapting education to all pupils. This problem is explained by the limited variation in approaches to teaching and the content of schooling, which favours academic subjects.

Issues concerning the variety of approaches to teaching and the content of schooling have also been addressed in the hearing process of the Green Paper NOU 2003:16. The Confederation of Norwegian Enterprise (NHO) argued for a more practical approach to lower secondary school by stating that basic competency, which was proposed to be included in the curriculum, should include the practical skill of 'mastering' in addition to generic theoretical skills, because 'VET demands mastering' (NHO, 2003: 4). Other organisations agreed that the Green Paper was 'inadequate concerning practical subjects' and arguing that the curriculum should also 'include a practical element, namely basic use of tools, technics and methods’ (see e.g. Opplæringsrådet for Tre- og Møbelfag, 2003: 2).

To respond to this policy problem through improved adapted education, several policy solutions were proposed to contribute to a more practical lower secondary education, namely, the introduction of elective subjects and the opportunity to attend modules from upper secondary education in addition to mandatory lower secondary education.

Both the introduction of electives and the opportunity to attend modules from upper secondary education are means to promote more practical education. During a debate in Stortinget concerning the promotion of more practical education, Kristin Clemet, who was Minister of Education at that time, emphasised that she considered this approach a good solution to meeting the challenges involved in offering adapted education, adding that she 'has a strong request that pupils experience more mastering in lower secondary education and that we can meet more pupils when a more practical lower secondary school is realised' (Stortinget, 2012: 1923). 
The introduction of electives was proposed in a White Paper (Ministry of Education, 2011) and realised gradually from the school year 2012-2013 onwards. All these electives in lower secondary school are interdisciplinary because they consist of two different main areas, include elements from several subjects and relate further to upper secondary education (Utdanningsdirektoratet, 2017).

Being able to attend modules from upper secondary education in addition to mandatory lower secondary education has been proposed both in the preparation of LK06 and after its introduction as part of different reform processes (Ministry of Education, 2004, 2009; NOU, 2003). In 2008, this opportunity was limited to the subjects mathematics, English, foreign language, science and social science (Utdanningsdirektoratet, 2018). In 2013, the subjects included were extended to comprise all subjects in upper secondary education and VET that build directly on lower secondary education and do not require any specific previous knowledge. The target group for this solution are academically strong pupils, who are given the chance to develop their abilities by attending modules from the upper secondary level. In addition to improving adapted education, this is an attempt to create a closer connection between lower and upper secondary education.

\section{Gap between the content of schooling and the world of work}

Another problem discussed in the documents is the lack of focus on the practical aspects of education, including a gap between education and the world of work. NHO pointed to this gap explicitly in the hearing process:

[T]he Green Paper [NOU 2003:16] has too much focus on school and the individual. [...] With the ambition to create better connections [. . . ] in the whole education system, the perspective on enterprises and the world of work has to be as visible as the one on education policy. (NHO, 2003:2)

In a Stortinget debate, several parties argued for the introduction of entrepreneurship to the education system, revealing that the members of Stortinget had a similar perspective to that expressed in the NHO's critique (Church, Education and Science Committee, 2011; Ministry of Education, 2011). The debate in the Stortinget showed that the parliament members wanted to solve this problem by establishing a stronger connection to and cooperation with the world of work; they also expressed a desire to educate the pupils in the areas of innovation and creativity, thereby strengthening their employability. Senterpartiet $(\mathrm{Sp})^{3}$ stressed this perspective by arguing that 'entrepreneurship in school is very important for creating our future business sector and thereby growth in the whole nation' (Stortinget, 2012: 1931). The proposed policy solution to this problem was a strategy for promoting entrepreneurship.

Several policy documents have proposed a strategy for entrepreneurship (Ministry of Education, 2004, 2009). As a result, the Ministry of Education developed two strategies for entrepreneurship, one for the 2004-2008 period and a second from 2009 to 2014 . Further, the inclusion of entrepreneurship as a topic in interdisciplinary electives has also been proposed (Ministry of Education, 2011). However, a search in the subjectcurricula for the electives(Utdanningsdirektoratet, 2017) shows that the only elective subject that includes entrepreneurship in the curriculum is production of products and service (Utdanningsdirektoratet, 2012). This indicates that entrepreneurship has not been enacted in the curriculum and schools as much as intended in the policy process.

These policy problems and solutions emphasising pre-vocational education and resulting in curriculum reform of LK06 can be better understood by considering the frame of the purpose of education and the role of the world of work in education. 


\section{The purpose of education and the role of the world of work in education}

The analysis of the policy documents shows that the purpose of education is described as both to educate the individual and to prepare the individual for life in society and the world of work. For instance, NOU 2003:16 stresses that society places two expectations on the education system: first, the education of 'good citizens' (NOU, 2003: 33) and, second, the education of 'good employees' (NOU, 2003: 33). Several documents emphasise the development towards the knowledge society and the involved requirements of the world of work (Ministry of Education, 2004, 2008, 2009; NOU, 2003). In White Paper no. 44 (Ministry of Education, 2009: 6), it is argued that 'the education system has to have the ability to respond to the needs of the world of work'. Further, human capital is considered to be society's most important resource, indicating that 'the population's competence is considered to be the most important factor in a country's economic production capacity today' (NOU, 2003: 33). It is estimated that $80 \%$ of the Norwegian national wealth consists of human resources and human capital (Ministry of Education, 2009). As such, an educated workforce that is able to meet the demands of society and the world of work is considered important. In other words, the purpose of education is to promote education in general, with a focus on employability in particular.

\section{Discussion}

The analysis reveals several policy problems that are intended to be addressed through policy solutions that emphasise pre-vocational education. One of these problems is the school dropout rate from upper secondary education. The proposed solutions to deal with this problem include providing more career guidance and giving pupils more practical experiences in school. These proposals have resulted in a new subject strengthening career guidance: the elective programme subject, which eventually became the mandatory subject choice of education. The elective world of worksubject has also been included in the curriculum to offer a practical approach and content to lower secondary education. The policy documents preparing the reform that resulted in LK06 included a proposal for a more practical subject, technology and design, which was not included in the curriculum.

The second problem discussed in the previous section concerns the challenges of adapting education to the pupils due to the small variety of approaches to teaching and the content of schooling, which mainly promote academic knowledge. The lack of practical approaches in lower secondary school has previously been addressed in replies from different organisations in the hearing process. The policy documents proposed the introduction of elective subjects to the lower secondary education curriculum from the school year 2012-2013 onwards. Another policy solution is providing the opportunity to attend modules from upper secondary level while in lower secondary school as a form of adapting education to academically stronger pupils.

The policy problem referred to as 'gap to the world of work' describes a lack of focus on the practical aspects of education and thereby a disconnection from the world of work. The proposed solutions were to focus on entrepreneurship in education and thereby to create a stronger connection to and cooperation with the world of work. Further, through a focus on entrepreneurship, the pupils could develop their abilities in innovation and creativity, which would strengthen their employability. This proposal resulted in two strategies for entrepreneurship for the periods 20042008 and 2009-2014, respectively. It was also proposed to emphasise entrepreneurship as part of the electives; however, this appears not to have been enacted accordingly. Table 1 shows an overview of the policy problems and solutions presented in this section. 
Table I. Policy problems and solutions.

\begin{tabular}{ll}
\hline Problem & Solution(s) \\
\hline $\begin{array}{l}\text { School dropout rate from } \\
\text { upper secondary education }\end{array}$ & - Career guidance: elective programme subject and \\
& choice of education \\
& - More practical experience in school: world of work- \\
& subject and technology and design (not included in \\
& LK06) \\
Challenges in adapting & - Introduction of elective subjects \\
education to the pupils & - Opportunity to attend modules from upper \\
& secondary in lower secondary school \\
Gap to the world of work & - Entrepreneurship: strategies for entrepreneurship \\
& for 2004-2008 and 2009-20 I4 and emphasising \\
& entrepreneurship as part of the electives (not \\
& enacted accordingly)
\end{tabular}

These policy problems and solutions can be understood in light of a special emphasis on the world of work and employability in the Norwegian educational discourse. Although the purpose of education is to educate the individual to become part of society, there is an increased focus on responding to the needs of the world of work and thereby strengthening the employability of the pupils.

\section{Complex policy problems}

The analysis of the policy documents and official hearings reveals three frames describing policy problems faced by the Norwegian comprehensive school system. These can be considered complex problems in line with Peters' (2017) definition of complexity. As Peters emphasises, most policy problems faced by governments nowadays cannot be solved in a final manner. This is, amongst others, due to the lack of clear solutions, as there is no linear relationship between the problem and an obvious solution. The three policy problems discussed in this article are likewise framed in such a way that they lack a linear relationship between the problem and any obvious solutions. For instance, the introduction of elective subjects can be a solution to adapt education to pupils, as described by the frames of policy problems and solutions. However, electives do not have an impact on adapted education in the other subjects; therefore, one might ask how big the impact of an elective subject is on the content of schooling, as the number of hours electives are taught is low compared to other mandatory subjects. The frame presenting the solution that focuses on career guidance, with the purpose of reducing dropout rates in upper secondary education, proposes to support pupils with their choice of upper secondary education and whether they prefer an academically oriented upper secondary school or VET. Therefore, the focus is narrowed down to the choice of upper secondary education, instead of dropout.

Furthermore, two of the framed policy problems are also framed as solutions for other policy problems. For instance, adapted education is a solution to the Norwegian comprehensive school system wherein all pupils attend the same school. However, as this study shows, adapted education cannot adequately meet all pupils' needs and interests. Therefore, it becomes a problem on another level, which, in turn, results in electives and the possibility of attending modules from the upper secondary school whilst being a pupil at lower secondary level. This example highlights the complexity of these problems and how they are intertwined with one another - either as problems or solutions. Therefore, one might wonder whether the actual problem is the Norwegian comprehensive school system, rather than the principle of adapted education.

The frame describing the policy problem concerning the gap between education and the world of work is also the solution to the problem. This is because one is trying to connect education and 
the world of work through entrepreneurship in school. This exemplifies that these complex problems are matched with rather simple solutions.

\section{Framing of problems and solutions and conflicting purposes and values in the education system}

The operationalisation of the theoretical concepts enables the identification of the frames that describe the policy problems and solutions presented in the previous sections. The documents convert certain situations in the Norwegian education system into problems and define particular actions as legitimate responses (Daviter, 2007; MacLachlan and Reid, 1994; van Hulst and Yanow, 2016). For instance, the dropout rate in Norwegian upper secondary education has been stable since the 1990s; however, it has only been considered as a problem for approximately a decade. The policy solutions emphasising pre-vocational education presented earlier discuss Norwegian lower secondary education. Nevertheless, the proposed policy means are not enacted accordingly. The analysis shows a difference between the framing of the solutions in the policy process (i.e. the rhetoric and formulations in the documents) and the actual policy reforms. For instance, it was proposed that the world of work-subject would become a mandatory elective to be offered by all schools; however, it was later determined that schools could decide whether they wanted to offer the subject.

Another example of the difference between the political and the programmatic levels is related to entrepreneurship. There was a proposal to include entrepreneurship in the electives, but it was realised for only one of the elective subjects.

These examples demonstrate that not all solutions are followed up on in line with the policy documents and what is passed in the debates in the Stortinget. Therefore, the solutions to the problems become less visible throughout the policymaking process. This shows that the enactment of lower secondary education is not in line with the discussions about lower secondary education and its characteristics and values in the policymaking process.

The approach to dealing with these identified policy problems is most likely weakened throughout the process. One possible explanation for the toning down of policy solutions in this process is the existence of conflicting values and purposes in the education system (Labaree, 1997). Equality is an important value in the Norwegian education system, as pupils should get equal access and opportunity (Imsen and Volckmar, 2014). On the one hand, one could argue that more electives can improve equal opportunities for the pupils, because they have a larger range of subjects to choose from and can select electives based on their interests and abilities. On the other hand, an increased number of electives can also result in less equality concerning access to education, as the pupils cannot attend all subjects. For instance, academic subjects have a consolidated position and a higher status in the curriculum (Goodson, 1995, 2001, 2014; Luimes and Karseth, 2019). Therefore, choosing pre-vocational education instead of more academic subjects may result in unequal opportunities as pupils attend different subjects. Depending on how equal access and opportunity are realised in the Norwegian education system, these values can be used as arguments either for or against electives and pre-vocational education.

The principle of adapted education does not necessarily require the introduction of pre-vocational education either, even though one could argue that offering different electives could be an approach to adapted education. However, following the principle of adapted education, the aim is to adjust education to the pupils independent of the subject.

Concerning the described purpose of education, a question arises as to whether educating individuals to become part of society and emphasising pupils' employability are two conflicting purposes. The described gap between education and the world of work shows that lower secondary school is unable to meet the demands of todays' world of work. The school dropout rate in upper secondary education supports this statement, as the education system cannot fulfil its purpose concerning the employability of pupils when they do not finish education. This could indicate that the 
purpose of providing general education for pupils is dominating the purpose of enhancing their employability and connecting school to the world of work.

\section{Pretending to problem-solve while accepting the problems}

The previous sections discuss the frames that describe three different complex problems found in the Norwegian comprehensive school system and their proposed solutions. There are indications leading to the conclusion that the purposes of Norwegian schooling are conflicting. As a result, policy means are not followed up and enacted in line with decisions made during the policymaking process. First, the high dropout rate indicates that many pupils do not complete upper secondary education; thus, neither the specific learning outcomes defined in the curriculum nor the aim that all pupils should attend and accomplish upper secondary education is realised. Second, the purpose of schooling to adapt education to pupils is not fulfilled to a satisfactory degree, as evidenced by the discussion about the composition of the curriculum. Third, the relevance of the content of schooling and the gap to the world of work, which is addressed in the policy documents and debated in parliament, is questioned. The fact that comprehensive schooling is facing difficulties is acknowledged in the policy documents, both through the discussions of these problems and through the proposed solutions that are debated and passed to deal with these problems. However, as discussed in the previous section, some of the solutions are toned down in the process. This understanding implies that pre-vocational education plays a less important role than that implied by official documents (Luimes and Karseth, 2019).

Despite the weakening of some solutions in the policymaking process, changes have been made in education policy and the curriculum through several means, such as the inclusion of new school subjects and the promotion of career guidance and entrepreneurship. This weakening demonstrates that there is an attempt within the existing education system to solve the problems Norwegian comprehensive school is facing. For instance, there have been no discussions about whether a stratified education system with different tracks could improve the possibility of offering adapted education. The reason for this could be that such a discussion would be in conflict with the purposes and values of Norwegian education, such as providing equal access and opportunities. This leads to the question of whether the solutions are only being proposed and enacted to pretend to solve the mentioned problems, despite actually accepting these problems. As discussed earlier, complex educational problems are rarely solved (Peters, 2017). Thus, this characteristic of complex problems highlights the notion of whether the government is simply pretending to solve the problems, especially given that, according to research, it is a more or less impossible task to solve complex policy problems. The question concerning problem-solving versus accepting the problems can be strengthened as the solutions are adapted to the existing comprehensive school system without debating more radical solutions, such as alternatives to the comprehensive school system. In addition, the conflicting values and purposes of schooling may be a reason for the reduced effectiveness of policy means that emphasise pre-vocational education and are enacted in schools. However, the solutions provide a certain structure that can give the impression of controlling these policy problems to a certain degree. This shows that the comprehensive school system has a strong stance in Norway, and policy problems and solutions might be part of the policymaking process. These findings also confirm that pre-vocational education plays a less important role in the curriculum than the impression given by the rhetoric used in official policy documents and debates.

\section{Conclusion}

This study investigated the different frames used to describe and make sense of policy reforms that promote pre-vocational education in Norwegian lower secondary education. In light of the frame 
emphasising the essential role of employability and the needs of the world of work in the current educational discourse, I have identified three policy problems in the documents that are intended to be addressed through pre-vocational education: (a) the dropout rate from upper secondary education; (b) the challenges involved in adapting education to the pupils due to the limited content of schooling; and (c) the gap between the content of schooling and the world of work. All three issues can be labelled as complex problems and are matched with solutions emphasising pre-vocational education, specifically career guidance, more practical experiences in school, the inclusion of electives, the opportunity to attend modules from upper secondary school in lower secondary education, and entrepreneurship.

The findings reveal a difference between the political and the programmatic levels; specifically, the rhetoric at the political level is stronger than its actual translation through curriculum reform at the programmatic level. A possible explanation for this is that some of the policy means are not in line with certain values and purposes of Norwegian education, resulting in conflicting policy means that are toned down in the policy process. Due to the toning down of policy means, pre-vocational education is given less importance than indicated in official documents and debates in Stortinget. Previous research has already suggested similar results concerning pre-vocational education in the curriculum (Luimes and Karseth, 2019). This detailed study of the official documents further substantiates the idea that the importance of pre-vocational education decreases from the political to the programmatic level. Such a difference could be related to autonomy in curriculum work at the programmatic level and the stability of the composition of the curriculum, in addition to conflicting values and purposes within the Norwegian education system. This finding challenges the view of pre-vocational education as a generally applicable policy solution to problems in lower secondary education as presented by the $\operatorname{OECD}(2011,2020)$, such as, for instance, school dropout.

Furthermore, the discrepancy between the rhetoric at the political level and its translation in the curriculum suggests that politics might have accepted the defined problems while largely pretending to deal with them through political rhetoric and window-dressing. This impression is further strengthened by the fact that the defined problems are addressed only within the existing education system. For instance, alternatives to the comprehensive school system can be discussed, such as a stratified education system, which is commonly used in other countries. However, this solution is not in line with the Norwegian approach to schooling and its emphasis on equity and inclusion (Imsen and Volckmar, 2014).

The findings of this study related to the toning down of policy means in policymaking also raise questions as to why passed policy means are not enacted accordingly. In relation to the enacted policy means, it would be of relevance to study how policies are enacted at the practical level in schools. However, these questions also represent a limitation of this study, as different data and study designs are necessary for investigating the toning down of policy means in policymaking and the enactment of policy solutions. Therefore, avenues for future research could be to investigate why some policy means are toned down, how solutions focusing on pre-vocational education are enacted in Norwegian lower secondary schools, and the kinds of experiences pupils, teachers or heads of schools have with these solutions.

\section{Acknowledgements}

The author would like to thank Berit Karseth, Britt Ulstrup Engelsen and Jens Jungblut for their thorough comments and feedback on an earlier version of this article.

\section{Declaration of conflicting interests}

The author declared no potential conflicts of interest with respect to the research, authorship and/or publication of this article. 


\section{Funding}

The author received no financial support for the research, authorship and/or publication of this article.

\section{ORCID iD}

Maike Luimes (iD https://orcid.org/0000-0001-6851-3070

\section{Notes}

1. LK06 was introduced in 2006 and was replaced by the new curriculum Knowledge Promotion 2020 (Kunnskapsløftet 2020), which is being gradually introduced to the Norwegian education system from August 2020 and onwards (Utdanningsdirektoratet, 2020).

2. See Appendix 2 for further information about the different political parties.

3. See Appendix 2 for further information about the different political parties.

\section{References}

Alexiadou N, Helgøy I and Homme A (2019) Lost in transition - policies to reduce early school leaving and encourage further studying in Europe. Comparative Education 55: 297-307.

Bakken A, Dæhlen M and Smette I (2013) Forsøk med arbeidslivsfag på ungdomstrinnet: Sluttrapport fra en følgeevaluering. NOVA Rapport 11/13 [Piloting the world of work-subject in lower secondary education: final report of a longitudinal evaluation. NOVA report 11/13]. Available at: https://oda.oslomet. no/oda-xmlui/bitstream/handle/20.500.12199/5061/7376_1.pdf?sequence=1\&isAllowed=y (accessed 9 September 2021).

Bateson G (1972) A theory of play and fantasy. In: Bateson G (ed.) Steps to an Ecology of Mind. San Francisco: Chandler, pp.150-166. 1955.

Béland D and Howlett M (2016) How solutions chase problems: Instrument constituencies in the policy process. Governance: An International Journal of Policy, Administration, and Institutions 29: 393-409.

Benford RD and Snow DA (2000) Frame processes and social movements. Annual Review of Sociology 26: 611-639.

Berger S, Canning R, Dolan M, et al. (2012) Curriculum-making in pre-vocational education in the lower secondary school: A regional comparative analysis within Europe. Journal of Curriculum Studies 44(5): 679-701.

Chong D and Druckman JN (2007) Framing theory. Annual Review of Political Science 10: 103-126.

Church, Education and Science Committee (2004) Innst. S. nr. 268 (2003-2004) Innstilling til Stortinget fra kirke, utdannings- og forskningskomiteen St.meld. nr. 30 (2003-2004) (Proposition no. 268 (2003-2004) to Stortinget from the Church, Education and Science Committee White Paper no. 30 (2003-2004)). Det kongelige Utdannings- og forskningsdepartementet (Ministry of Education and Research). Available at: https://www.stortinget.no/no/Saker-og-publikasjoner/Publikasjoner/Innstillinger/Stortinget/2003-2004/ inns-200304-268/?lvl=0 (accessed 9 September 2021).

Church, Education and Science Committee (2008) Innst. S. nr. 42 (2008-2009) Innstilling til Stortinget fra kirke, utdannings- og forskningskomiteen St.meld. nr. 31 (2007-2008) (Proposition no. 42 (2008-2009) to Stortinget from the Church, Education and Science Committee White Paper no. 31 (2007-2008)). Det kongelige Utdannings- og forskningsdepartementet (Ministry of Education and Research). Available at: https://stortinget.no/nn/Saker-og-publikasjonar/publikasjonar/Innstillingar/Stortinget/2008-2009/inns200809-042/ (accessed 9 September 2021).

Church, Education and Science Committee (2011) Innst. S. nr. 145 (2011-2012) Innstilling til Stortinget fra kirke, utdannings- og forskningskomiteen Meld.St. 22 (2010-2011) (Proposition no. 145 (2011-2012) to Stortinget from the Church, Education and Science Committee White Paper no. 22 (2010-2011)). Det kongelige Utdannings- og forskningsdepartementet (Ministry of Education and Research).

Coburn CE (2006) Framing the problem of reading instruction: Using frame analysis to uncover the microprocesses of policy implementation. American Educational Research Journal 43(3): 343-379. 
Coburn CE, Toure J and Yamashita M (2009) Evidence, interpretation, and persuasion: Instructional decision making at the district central office. Teachers College Record 111(4): 1115-1161.

Confederation of Norwegian Enterprise (NHO) (2003) Høring: Kvalitetsutvalgets innstilling og andre aktuelle problemstillinger NOU 2003:16 [Consultation: The Quality Committee's recommendation and others current issues NOU 2003: 16].

Cuban L (1990) Reforming again, again, and again. Educational Researcher 19(1): 3-13.

Daviter F (2007) Policy framing in the European Union. Journal of European Public Policy 14(4): 654-666. Gioia DA and Chittipeddi K (1991) Sensemaking and sensegiving in strategic change initiation. Strategic Management Journal 12(3): 433-448.

Goffman E (1974) Frame Analysis. New York: Harper \& Row

Goodson I (1995) The Making of Curriculum. Collected Essays. 2nd edn. Washington DC: Falmer Press.

Goodson I (2001) Social histories of educational change. Journal of Educational Change 2: 45-63.

Goodson I (2014) Context, curriculum and professional knowledge. History of Education 43(6): 768-776.

Hopmann ST (1999) The curriculum as a standard of public education. Studies in Philosophy and Education 18: 89-105.

Imsen G and Volckmar N (2014) The Norwegian school for all: Historical emergence and neoliberal confrontation. In: Blossing U, Imsen G and Moos L (eds) The Nordic Education Model: 'A School for All' Encounters Neo-Liberal Policy. Dordrecht: Springer, pp.35-55.

Karseth B and Engelsen BU (2013) Læreplanen for kunnskapsløftet: Velkjente tråkk og nye spor (The curriculum of knowledge promotion: Familiar trails and new tracks). In: Karseth B, Møller J and Aasen P (eds) Reformtakter: Omfornyelse og stabilitet i grunnopplceringen (Reform measures about renewal and stability in basic education). Oslo: Universitetsforlaget, pp.43-60.

Karseth B and Møller J (2020) Legal regulation and professional discretion in schools. Scandinavian Journal of Educational Research 64(2): 195-210.

Kingdon JW (1995) Agendas, Alternatives, and Public Policies. New York: Longman.

Kunnskapsdepartementet (2012) Strategi for ungdomstrinnet: Motivasjon og mestring for bedre læring Felles satsing på klasseledelse, regning, lesing og skriving [Motivation and mastery for better learning - Joint focus on classroom management, arithmetic, reading and writing]. Available at: http://www. regjeringen.no/upload/KD/Vedlegg/Grunnskole/Strategiplaner/F_4276B_strategi_for_ungdomstrinnet. pdf (accessed 9 September 2021).

Kunnskapsdepartementet (2014) Arbeidslivsfag som eit alternativ til framandspråk [The world of work-subject as an alternative to second foreign language]. Available at: https://www.regjeringen.no/no/aktuelt/ arbeidslivsfag-som-eit-alternativ-til-fr/id751477/ (accessed 9 September 2021).

Labaree DF (1997) Public goods, private goods: The American struggle over educational goals. American Educational Research Journal 34(1): 39-81.

Luimes M and Karseth B (2019) Pre-vocational education in the curriculum: The case of Norwegian lower secondary education. Journal of Curriculum Studies 51(2): 245-261.

MacLachlan G and Reid I (1994) Framing and interpretation. Melbourne: Melbourne University Press.

Ministry of Education (2004) Kultur for laering (Culture for learning). Det kongelige Utdannings- og forskningsdepartementet (Ministry of Education). White Paper no. 30 (2003-2004). Oslo: Ministry of Education.

Ministry of Education (2008) Kvalitet $i$ skolen (Quality in school). White Paper no. 31 (2007-2008). Oslo: Ministry of Education.

Ministry of Education (2009) Utdanningslinja (Education Strategy). White Paper no. 44 (2008-2009). Oslo: Ministry of Education.

Ministry of Education (2011) Motivasjon - mestring - muligheter - ungdomstrinnet (Motivation - mastering - opportunities - lower secondary education). White Paper no. 22 (2010-2011). Oslo: Ministry of Education.

Ministry of Education (2013) På rett vei - kvalitet og mangfold i fellesskolen (On the right path - quality and diversity in comprehensive school. White Paper no. 20 (2012-2013). Oslo: Ministry of Education.

Mølstad CE, Prøitz TS and Dieude (2020) When assessment defines the content: Understanding goals in between teachers and policy. Curriculum Journal 32(2): 290-314. 
NOU (2003) NOU 2003:16: I første rekke - forsterket kvalitet i grunnopplaeringen for alle (Green Paper 2003:16: In the first row - increased quality within a basic education system for everyone). Oslo: Ministry of Education and Research.

NTB (2020) Flere privatskoler i Norge enn noen gang [More private schools in Norway than ever before]. Available at: https://forskning.no/barn-og-ungdom-ntb-politikk/flere-privatskoler-i-norge-enn-noengang/1621335 (accessed 9 September 2021).

Nylund M and Rosvall P- $\AA$ (2019) Vocational education, transitions, marginalisation and social justice in the Nordic countries. European Educational Research Journal 18(3): 271-277.

Organisation for Economic Co-operation and Development (2011) Reviews of national policies for education: Improving lower secondary schools in Norway 2011. Available at: https://www.oecd-ilibrary. org/education/improving-lower-secondary-schools-in-norway-2011_9789264114579-en (accessed 9 September 2021)

Organisation for Economic Co-operation and Development (2020) Secondary graduation rate. Available at: https://data.oecd.org/students/secondary-graduation-rate.htm (accessed 9 September 2021).

Opplæringsrådet for Tre- og Møbelfag (2003) Høring: Kvalitetsutvalgets innstilling og andre aktuelle problemstillinger [Consultation: The quality committee's recommendation and other current issues].

Peters BG (2017) What is so wicked about wicked problems? A conceptual analysis and a research program. Policy and Society 36: 385-396.

Prøitz TS, Rye E and Aasen P (2019) Nasjonal styring og lokal praksis - skoleledere og lærere som endringsagenter [National governance and local practice - school leaders and teachers as agents of change]. In: Jensen R, Karseth B and Ottesen E (eds) Styring og ledelse i grunnopplceringen: Spenninger og dynamikker [Management and leadership in basic education: Tensions and dynamics]. Oslo: Cappelen Damm Akademisk, pp.21-38.

Rein M and Schön DA (1977) Problem setting in policy research. In: Weiss CS (ed.) Using Social Research in Public Policy Making. Lexington: Lexington Books, pp.235-251.

Ricoeur P (1981) Hermeneutics and the Human sciences: Essays on Language, Action and Interpretation. Cambridge: Cambridge University Press.

Rittel HWJ and Webber MM (1973) Dilemmas in the general theory of planning. Policy Sciences 4: 155-169.

Scholl D (2012) Are the traditional curricula dispensable? A feature pattern to compare different types of curriculum and a critical view of educational standards and essential curricula in Germany. European Educational Research Journal 11(3): 328-341.

Sivesind K, Van den Akker J and Rosenmund M (2012) The European curriculum: Restructuring and renewal. European Educational Research Journal 11(3): 320-327.

Stortinget (2012) Møte mandag den 9. januar 2012 kl. 12 (Meeting Monday 9 January 201212 p.m.). Oslo: Stortinget.

Stortinget (2017) Lovarbeidet [The law work]. Available at: https://www.stortinget.no/no/Stortinget-ogdemokratiet/Arbeidet/Lovarbeidet/ (accessed 9 September 2021).

Stortinget (2018) Saksgangen [Proceedings]. Available at: https://www.stortinget.no/no/Stortinget-ogdemokratiet/Storting-og-regjering/Saksgangen-etter-1-10-2009/ (accessed 9 September 2021).

Sundberg D and Wahlström N (2012) Standards-based curricula in a denationalised conception of education: The case of Sweden. European Educational Research Journal 11(3): 342-356.

Telhaug AO, Mediås OA and Aasen P (2004) From collectivism to individualism? Education as nation building in a Scandinavian perspective. Scandinavian Journal of Educational Research 48(2): 141-158.

Telhaug AO, Mediås OA and Aasen P (2006) The Nordic model in education: Education as part of the political system in the last 50 years. Scandinavian Journal of Educational Research 50(3): 245-283.

Utdanningsdirektoratet (2012) Læreplan i valfaget produksjon av varer og tenester [Curriculum in the elective subject production of goods and services]. Available at: http://data.udir.no/k106/PVT1-01.pdf (accessed 9 September 2021).

Utdanningsdirektoratet (2015) Læreplan for arbeidslivsfag på ungdomstrinnet [Curriculum for working life subjects at the lower secondary level]. Available at: http://data.udir.no/k106/ARB1-02.pdf (accessed 9 September 2021). 
Utdanningsdirektoratet (2017) Valgfag [Electives]. Available at: https://www.udir.no/laring-og-trivsel/lareplanverket/fag/valgfag/ (accessed 15 July 2017).

Utdanningsdirektoratet (2018) Elever som tar fag fra videregående opplæring på ungdomstrinnet Udir-4-2013 [Students taking subjects from upper secondary education at the upper secondary level Udir-4- 2013]. Available at: https://www.udir.no/regelverkstolkninger/opplaring/Innhold-i-opplaringen/Udir-042013?depth $=0 \&$ print $=1$ (accessed 9 September 2021).

Utdanningsdirektoratet (2020) Innføring av nye læreplaner [Introduction of new curricula]. Available at: https://www.udir.no/laring-og-trivsel/lareplanverket/fagfornyelsen/innforing-av-nye-lareplaner/ (accessed 9 September 2021).

van Hulst M and Yanow D (2016) From policy 'frames' to 'framing': Theorizing a more dynamic, political approach. American Review of Public Administration 46(1): 92-112.

Verger A (2012) Framing and selling global education policy: The promotion of public-private partnerships for education in low-income contexts. Journal of Education Policy 27(1): 109-130.

Young M (2008) Bringing Knowledge Back In: From Social Constructivism to Social Realism in the Sociology of Education. London: Routledge.

\section{Author biography}

Maike Luimes works at Kristiania University College. Her primary research interests are in the areas of education policy, reforms and curriculum studies. This article is part of her PhD study at the University of Oslo focusing on curriculum policy and practice in pre-vocational education in Norwegian lower secondary schooling. 
Appendix I. List of official documents included in this study.

- NOU 2003:16. I første rekke: Forsterket kvalitet i en grunnopplæring for alle (Green Paper 2003:16: In the first row - increased quality within a basic education system for everyone).

- Høring: NOU 2003: 16 . I første rekke: Forsterket kvalitet i en grunnopplæring for alle (Official hearing: Green Paper 2003:16: In the first row - increased quality within a basic education system for everyone).

- St. meld. nr. 30 (2003-2004) Kultur for læring (White Paper no. 30 (2003-2004) Culture for learning).

- Innst. S. nr. 268 (2003-2004) Innstilling til Stortinget fra kirke, utdannings- og forskningskomiteen St. meld. nr. 30 (2003-2004) (Proposition no. 268 (2003-2004) to Stortinget from the Church, Education and Science Committee White Paper no. 30 (2003-2004)).

- Behandling og vedtak i Stortinget St. meld. nr. 30 (2003-2004), Innst. S. nr. 268 (2003-2004) (Protocol of discussions and resolutions in Stortinget - White Paper no. 30 (2003-2004), Proposition no. 268 (2003-2004)).

- St. meld. nr. 16 (2006-2007) . . og ingen sto igjen. Tidlig innsats for livslang læring (White Paper no. 16 (2006-2007) . . . No one left behind. Early intervention for lifelong learning).

- Innst. S. nr. 164 (2006-2007) Innstilling til Stortinget fra kirke, utdannings- og forskningskomiteen St. meld. nr. 16 (2006-2007) (Proposition no. 164 (2006-2007) to Stortinget from the Church, Education and Science Committee White Paper no. 16 (2006-2007)).

- Behandling og vedtak i Stortinget St. meld. nr. 16 (2006-2007), Innst. S. nr. 164 (2006-2007) (Protocol of discussions and resolutions in Stortinget - White Paper no. 16 (2006-2007), Proposition no. 164 (2006-2007)).

- St. meld. nr. 3 I (2007-2008) Kvalitet i skolen (White Paper no. 3 I (2007-2008) Quality in school).

- Innst. S. nr. 42 (2008-2009) Innstilling til Stortinget fra kirke, utdannings- og forskningskomiteen St. meld. nr. 31 (2007-2008) (Proposition no. 42 (2008-2009) to Stortinget from the Church, Education and Science Committee White Paper no. 31 (2007-2008)).

- Behandling og vedtak i Stortinget St.meld. nr. 3 I (2007-2008), Innst. S. nr. 42 (2008-2009) (Protocol of discussions and resolutions in Stortinget - White Paper no. 3I (2007-2008), Proposition no. 42 (2007-2008)).

- St. meld. nr. 44 (2008-2009) Utdanningslinja (White Paper no. 44 (2008-2009) Education strategy).

- Innst. 192 S (2009-2010) Innstilling til Stortinget fra kirke, utdannings- og forskningskomiteen St. meld. nr. 44 (2008-2009) (Proposition no. 192 (2009-2010) to Stortinget from the Church, Education and Science Committee White Paper no. 44 (2008-2009)).

- Behandling og vedtak i Stortinget St. meld. nr. 44 (2008-2009), Innst. I92 S (2009-2010) (Protocol of discussions and resolutions in Stortinget - White Paper no. 44 (2008-2009), Proposition no. 192 (2009-20I0)).

- Meld. St. 22 (20I0-20II) Motivasjon - mestring - muligheter - ungdomstrinnet (White Paper no. 22 (20I0-20I I) Motivation - mastering - opportunities - lower secondary education).

- Innst. I45 S (20II-20I2) Innstilling fra kirke-, utdannings- og forskningskomiteen om Meld. St. 22 (20I0-20I I). (Proposition no. I 45 (20I I-20I2) to Stortinget from the Education and Science Committee White Paper no. 22 (2010-20II))

- Behandling og vedtak i Stortinget Meld. St. 22 (20 I0-20 I I), Innst. I45 S (20I I-20I2) (Protocol of discussions and resolutions in Stortinget - White Paper no. 22 (2010-20I I), Proposition no. I45 (20II-20I2)).

- Meld. St. 20 (2012-20I3) På rett vei - kvalitet og mangfold i fellesskolen (White Paper no. 20 (20122013) On the right path - quality and diversity in comprehensive school).

- Innst. 432 S (20I2-20I3) Innstilling fra kirke-, utdannings- og forskningskomiteen om Meld. St. 20 (Proposition no. 432 (20l2-2013) to Stortinget from the Church, Education and Science Committee White Paper no. 20 (20I2-20I3)).

- Behandling og vedtak i Stortinget Meld. St. 20 (20I2-20I3), Innst. 432 S (20I2-20I3) (Protocol of discussions and resolutions in Stortinget - White Paper no. 20 (20I2-20I3), Proposition no. 432 (20I2-20I3)). 
Appendix 2. Political parties and party families.

\begin{tabular}{lll}
\hline Party & Abbreviation & Party family \\
\hline Fremskrittspartiet & $\mathrm{FrP}$ & Right wing populist party \\
Kristelig Folkeparti & $\mathrm{KrF}$ & Christian democratic party \\
Senterpartiet & $\mathrm{Sp}$ & Agrarian party \\
Venstre & $\mathrm{V}$ & Liberal party \\
\hline
\end{tabular}

